\title{
Valvular disease in patients with active sle and clinical suspicion of acute myocarditis : assesment by cardiovascular magnetic resonance
}

\section{Cielmar G Abarca}

From 18th Annual SCMR Scientific Sessions

Nice, France. 4-7 February 2015

\section{Background}

Systemic lupus erythematosus (SLE) is a disease of autoinmune origin that may involve numerous internal organs of the body. It is associated with high cardiovascular morbility and mortality. The cardiovascular magnetic resonance (CMR) provides us with a global evaluation of patients with active SLE and clinical suspicion of acute myocarditis. OBJETIVES The aim of study was the identification of cardiac alterations in patients with active SLE and clinical suspicion of acute myocarditis.

\section{Methods}

A total of twenty - eight patients were included in the study, with an average age of 30.7 years ( SD 12.7 yrs), 96\% female, diagnosed by criteria of American College or Rheumatology (ACR). Cardiovascular magnetic resonance (CMR) was performed on a $1.5 \mathrm{~T}$ scanner and include the following sequences: steady- state free precession, STIR
T2 weighted (Ts-2W), T1- Weighted spin - echo before and after gadolinium injection and late enhancement.

\section{Results}

The ejection fraction of left ventricle $<50 \%$ was found in $54 \%, 83.4 \%$ with contractility alterations, $87.5 \%$ with valvulitis and affection of the subvalvular apparatus in $50 \%$, pericardial effusion was observed in $62.5 \%$ and tissue characterization suggestive of myocarditis for the Lake Louise criteria were found to have global and relative enhancement in 37.7 and $50 \%$ respectively and late gadolinium enhancement (LGE) in 66.7\%.

\section{Conclusions}

In our study group we found that patients with acute myocarditis asoociated with SLE have a high incidence of valvulitis and affection of the subvalvar apparatus.

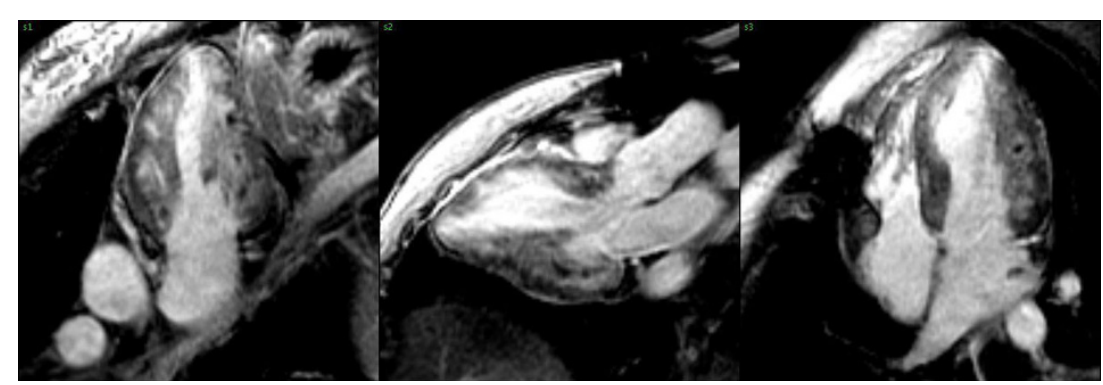

Figure 1 


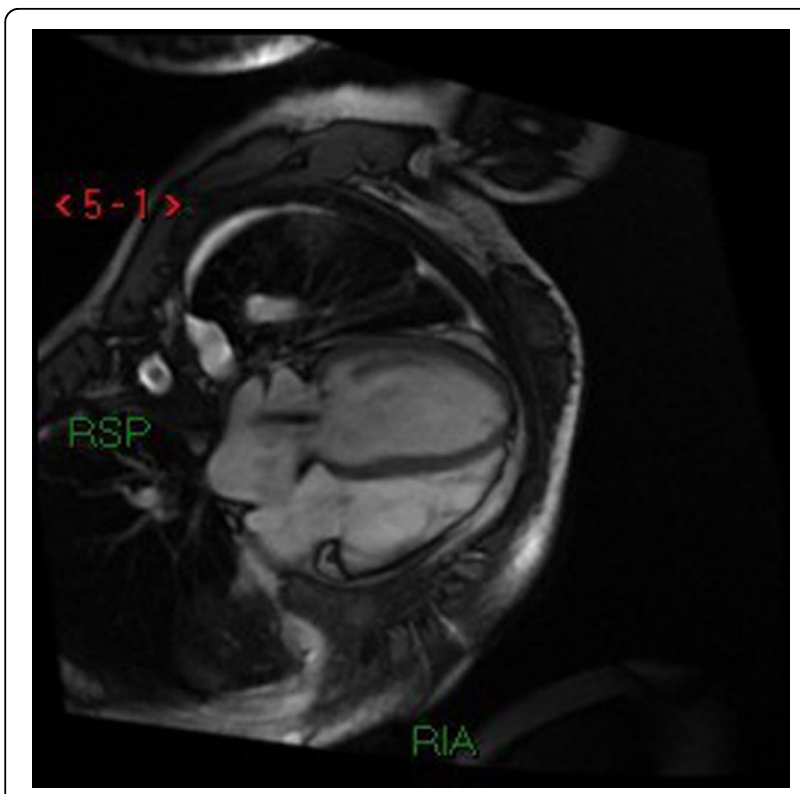

Figure 2

Published: 3 February 2015

doi:10.1186/1532-429X-17-S1-P298

Cite this article as: Abarca: Valvular disease in patients with active sle and clinical suspicion of acute myocarditis : assesment by

cardiovascular magnetic resonance. Journal of Cardiovascular Magnetic Resonance 2015 17(Suppl 1):P298.
Submit your next manuscript to BioMed Central and take full advantage of:

- Convenient online submission

- Thorough peer review

- No space constraints or color figure charges

- Immediate publication on acceptance

- Inclusion in PubMed, CAS, Scopus and Google Scholar

- Research which is freely available for redistribution

Submit your manuscript at www.biomedcentral.com/submit
C Biomed Central 